\title{
Is Gene Therapy Really Fruitful for Osteoarthritis?
}

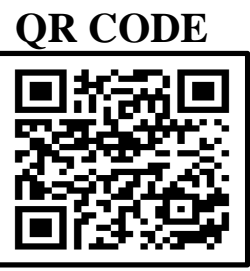

\section{JAYEETA CHOWDHURY*1, DATTATREYA MUKHERJEE², (D DEBRAJ MUKHOPADHYAY3 (D)}

Strategies have been categorized into two focus areas for the delivery of nucleic acids to weakened, diseased tissues: viral and non-viral gene therapy. In this commentary we address the implementation of osteoarthritis (OA) gene therapy as one of the most prevalent types of arthritis. We mostly concentrate on the gene therapy and cell therapy without a virus. We address briefly the benefits and the drawbacks of viral and non-viral gene therapy and stress upon the nucleic acid transport mechanisms used for transmitting gene to synovial joint articular chondrocytes. While viral gene delivery has become more common because of the efficiency published, considerable efforts have been made to improve the efficiency for transfecting non-viral transmission by promising tools for further use in simple, translational and clinical OA trials. Non-viral gene delivery technology has the ability to change the possible production of OA and osteoarticular diseasemodifying therapeutics.

Additional research is required to improve gene expression transfection effectiveness, durability and length of time. Osteoarthritis (OA) is one of the leading reason of disability all around the world and a highest cost contributor to health as well as social care systems. ${ }^{1}$ In the aspect of prevalence, OA is the most ordinary chronic and degenerative disease of synovial joints. ${ }^{2}$ The incidences of $\mathrm{OA}$ are increasing among the aging population because of the epidemic of obesity.3.4 Articular cartilage deterioration and degradation are characterized by OA and result in extreme pain, joint loss and decreased quality of life. ${ }^{5}$ As an alternative way to distribute therapeutic agents, growth factor genes and small regulatory components as microRNA, some methods to gene transmission are proposed. ${ }^{6,7}$ Finally, there have been progresses in the advancement of gene therapy approaches and technology to test them on experimental and translational OA models. Further studies are required, however, to maximize the gene expression transfer efficiency and length.

\section{REFERENCES}

1. Hunter DJ, Bierma-Zeinstra S. Osteoarthritis. Lancet. $\quad 2019 \quad$ Apr 27;393(10182):1745-59. https://doi.org/10.1016/So140-6736(19)30417-9.

2. Lories RJ, Luyten FP. The bone-cartilage unit in osteoarthritis. Nat Rev Rheumatol. 2011;7(1):43-9. https://doi.org/10.1038/nrrheum.2010.197.(1):43-9.

3. Messier SP. Obesity and osteoarthritis: disease genesis and nonpharmacologic weight management. Rheum Dis Clin North Am. 2008;34(3):713-29. https://doi.org/10.1016/j.rdc.2008.04.007.2008;34(3): 713-29.

4. King LK, March L, Anandacoomarasamy A. Obesity \& osteoarthritis. Indian J Med Res. 2013;138:185-93. 5. Bliddal H, Leeds A, Christensen RJ. Osteoarthritis, obesity and weight loss: evidence, hypotheses and horizons-a scoping review. Obes Rev. 2014;15(7):57886. https://doi.org/10.1111/obr.12173.2014;15(7):578-86. 6. Buckwalter JA, Mankin HJ, Grodzinsky AJ. Articular cartilage and osteoarthritis. Instr Course Lect. 2005;54:465-80.

7. Grol MW, Lee BH. Gene therapy for repair and regeneration of bone and cartilage. Curr Opin Pharmacol. 2018; 40:59-66. https://doi.org/10.1016/j.coph.2018.03.005.2018;40:5966. 
Cite this article as:

Chowdhury J, Mukherjee D, Mukhopadhyay D. Is Gene Therapy really fruitful for Osteoarthritis?. Int Healthc

https://doi.org/10.26440/IHRJ/0501.04405

\section{AUTHOR AFFILIATIONS:}

1. P.G Scholar, School of Biotechnology, KIIT University, Bhubaneswar, Odisha, India,

2. MBBS student and Research Assistant, Jinan University, 601 Huangpu W Ave, Tian He Gong Yuan, Tianhe District, Guangzhou, Guangdong Province, China. (https://orcid.org/oooo-ooo1-7566-3843)

3. Dept. of Public Health, School of Allied Health Sciences, Delhi Pharmaceutical Sciences and Research University (DPSRU), Govt. of N.C.T Delhi, New Delhi - 110017. (https://orcid.org/oooo-0003-4856-9012)

e-mail id for correspondence: jayeetachog8[at]gmail[dot]com 